Gitation: Castillo Mercado, R. A., Ramos Juárez J. A., Bucio Galindo A., \& Herrera-Corredor, J.A. (2021) Hedonic perception and preference analysis of double cream cheeses formulated with raw and pasteurized milk. Agro Productividad. https://doi.org/ 10.32854/agrop.v14i10.2008

Editor in Chief: Dr. Jorge Cadena Iñiguez

Received: April 26, 2021. Accepted: October 19, 2021.

Published on-line: November 8, 2021

This work is licensed under a Creative Commons Attribution-NonCommercial 4.0 International license.

\section{Hedonic perception and preference analysis of double cream cheeses formulated with raw and pasteurized milk}

\author{
Castillo Mercado, R. A. ${ }^{1}$, Ramos Juárez J. A. ${ }^{1}$, Bucio Galindo A. ${ }^{{ }^{*}}$, Herrera-Corredor, J. A. ${ }^{2}$ \\ 1 Colegio de Postgraduados Campus Tabasco, Km. 3.5 Periférico Carlos A. Molina S/N, H. Cárdenas, \\ Tabasco. CP 86500. México. \\ 2 Colegio de Postgraduados Campus Córdoba, Carretera Federal Córdoba-Veracruz km 348, Manuel León, \\ Amatlán de los Reyes, Veracruz, México, C. P. 94946. \\ * Correspondence: adbucio@colpos.mx
}

\begin{abstract}
Objective: To compare the characteristics of double cream cheeses made with raw and pasteurized milk per liking and preference level.

Design/Methodology/Approach: Cheeses from three brands were evaluated: Santa Teresa, Montero, and Colegio de Postgraduados (CP). The first two cheeses were formulated with raw milk, while the GP cheese was formulated with pasteurized milk inoculated with lactic cultures. The hedonic perception study was carried out in monadic series with 19 volunteers who blind tasted the three types of cheese. The evaluation attributes were: appearance, taste, aroma, and general acceptability on a 9-point scale; and saltiness, acidity, and creaminess on a 3-point scale (JAR). Preferences were evaluated by rank and multiple comparison tests.

Results: No differences were found in the aroma, taste, and texture liking level of the cheeses $(\mathrm{p}>0.05)$; nevertheless, there were differences in the appearance and general acceptance $(p<0.05)$. The general acceptance of the CP cheese was significantly lower than that of the two raw milk cheeses $(\mathrm{p}<0.05)$. The penalty analysis showed that low acidity and low creaminess attributes are related to a low general acceptance $(\mathrm{p}<0.05)$.

Limitations/Implications: The study has enough evaluations for statistical tests.

Findings/Conclusions: Raw milk cheeses obtained the highest marks in all attributes. Determining if there are other sensory attributes - in addition to those that were the subject of this study - will help to explain the greater preference and global acceptance of raw milk cheeses.
\end{abstract}

Keywords: pasteurized milk cheese, lactic cultures, raw milk cheese, liking level.

\section{INTRODUGTION}

Raw milk artisan cheeses are appreciated by consumers due to their unique taste and aroma: they are generally linked to the regions and local traditions of the sites where they are made. From a chemical point of view, the taste and aroma of cheeses depend on 
the physicochemical and microbiological composition of raw milk and the technological manufacturing characteristics (for example: heat treatment or pressing) of each type of cheese. Beuvier et al. (1997) showed that the raw milk of Swiss cheeses contains the microorganisms that generate their typical taste and aroma.

Cheeses made with raw milk generally have greater microbial and sensory diversity than cheeses made with pasteurized milk, which in many cases gives them a sensory advantage (Tadjine et al., 2020) (Table 1).

Pasteurization is a process in which raw milk is heated to $63{ }^{\circ} \mathrm{C} / 30$ min or $72{ }^{\circ} \mathrm{C} / 15$ min to eliminate pathogenic microorganisms and undesirable bacteria (Yoon et al., 2016). Milk composition, nutritional profile, and sensory properties may be slightly affected (Alegbeleye et al., 2018). Grappin and Beuvier (2007) also mention: elimination of milk microorganisms, inactivation of milk autochthonous enzymes, denaturation of whey proteins, and modification of the curdling properties of milk.

Using a heat treatment to pasteurize the milk that will be used to make cheeses requires harmless acidifying cultures (lactic cultures) that restore some of the microorganisms lost in pasteurization; this guarantees the acidification of the milk (Ramos et al., 2009; Saidi et al., 2020). Lactic acid bacteria are one of the main bacteria that can be safely (GRAS) inoculated into milk to acidify it with lactic acid from lactose. Lactic acid not only give the pleasant taste typical of many cheeses, it also has antimicrobial properties (Pacheco and

Table 1. Pros and cons of artisanal cheeses made with either raw milk or pasteurized milk.

\begin{tabular}{|c|c|c|}
\hline & Cheeses made with raw milk & Cheeses made with pasteurized milk \\
\hline Pros & $\begin{array}{l}\text { - Many cheese varieties made with raw milk have better taste, } \\
\text { aroma, and organoleptic characteristics than the same cheeses } \\
\text { styles made with pasteurized milk. } \\
\text { - These cheeses contain many microorganisms that produce } \\
\text { flavor and aromas, which are associated with greater consumer } \\
\text { preference (Montel } \text { et al., 2014). } \\
\text { - Many traditional cheeses are gastronomic elements of great } \\
\text { value because their distinctive flavors and textures. } \\
\text { - Its production is linked to value chains that generate local } \\
\text { employment. } \\
\text { - Products for the nostalgic market segment (Beuvier et al., 1997). } \\
\text { Immigrants away from their home country, do everything possible } \\
\text { to consume products that make them to remind their childhood. } \\
\text { - Some raw milk cheeses can be legally accepted, under the } \\
\text { specifications described in NMX-F-735 (2011). } \\
\text { - Some cheeses can be formulated with raw milk with low level } \\
\text { of microbial safety concern due to technological particularities } \\
\text { such as high acidity and high salty level (Pacheco and Bucio } 2010 \text {; } \\
\text { Bucio et al., 2021). }\end{array}$ & $\begin{array}{l}\text { - During milk pasteurization, microorganisms of all kinds are } \\
\text { eliminated. } \\
\text { - The national and international standards of heat treatment are } \\
\text { accomplished (Yoon } \text { et al., 2016). } \\
\text { - After pasteurization, milk is ready to be inoculated with lactic } \\
\text { cultures to make artisan style cheeses or any other type of cheeses, } \\
\text { including European style cheeses. } \\
\text { - The flavors of cheeses made with pasteurized milk depend } \\
\text { mainly on the microorganisms used in the inoculation. } \\
\text { - Practically all cheeses sold in self-service stores are made using } \\
\text { pasteurized milk. } \\
\text { - Cheeses made using pasteurized milk, especially European } \\
\text { cheeses have very attractive sensory characteristics for all types } \\
\text { of consumers. } \\
\text { - Many European artisan cheeses, even with Protected } \\
\text { Designation of Origin, are also made with pasteurized milk; or } \\
\text { have some heat treatment on the curd, p. Eg in scalding that } \\
\text { eliminates pathogenic microorganisms, such as pasta filata cheese. }\end{array}$ \\
\hline Cons & $\begin{array}{l}\text { - In many cheeses, sanitary quality might be variable (Pomeón } \\
\text { et al., } 2011 \text { ). } \\
\text { - Some cheese varieties are prompt to contain certain pathogenic } \\
\text { microorganisms. } \\
\text { - Sales are carried out only in the informal markets. } \\
\text { - Many cheeses do not meet national or international standards } \\
\text { for sale in formal markets, including self-service chain stores and } \\
\text { export markets (Tadjine } \text { et al., 2020). }\end{array}$ & $\begin{array}{l}\text { - If pasteurized milk is not inoculated with the specific flavor- } \\
\text { imparting microorganisms in raw milk cheeses, the flavors will be } \\
\text { very different. } \\
\text { - Some consumers are not used to enjoy the taste, aroma, and } \\
\text { texture of many of the cheeses made with pasteurized milk } \\
\text { (Alegbeleye } \text { et al., 2018), but they are used to cheeses with raw } \\
\text { milk (Villanueva, 2010). }\end{array}$ \\
\hline
\end{tabular}


Bucio, 2010). Many raw milk cheeses also contain other microorganisms that produce other types of acids or that have functions other than acidifying, but they are not usually added to the milk that is used to make pasteurized milk cheeses; this could have an impact on taste. For example, double cream cheeses made with raw milk have yeasts in addition to lactic bacteria (Ramos et al., 2009). No studies have been carried out to evaluate the taste of double cream cheeses formulated with raw milk and pasteurized milk to which lactic cultures that include yeasts have been added. Therefore, the hedonic perception and preference analysis of double cream cheeses made with raw and pasteurized milk were compared.

\section{MATERIALS AND METHODS}

This research was carried out at the Colegio de Postgraduados, Campus Tabasco. Cheeses from three brands were randomly collected. The cheeses formulated with raw milk were Sta. Teresa and Montero, both regionally prestigious brands. The CP cheese was made by Caobanal, a younger company, which has equipment to pasteurize milk. This company used the following mixed lactic culture, prepared by the Colegio de Postgraduados, Campus Tabasco: $>1 \times 10^{8} / \mathrm{g}$ of Lactobacillus fermentum, and $>1 \times 10^{8} / \mathrm{g}$ of Lactobacillus pentosus/plantarum (Ramos et al., 2009), as well as a proteolytic yeast strain (Duran, in preparation). The first two strains acidify milk; the third strain hydrolyzes caseins to peptones. Therefore, all of them increase the amino acid availability for milk acidification. The presence of yeast in double cream cheese manufactured with raw milk inspired us to suggest its use (Ramos et al., 2009). This culture was multiplied by the Caobanal company about 6 times; they used it to process 6 sets of $100 \mathrm{~kg}$ of milk and they obtained about $600 \mathrm{~kg}$ in total. The company was invited to exhibit its cheeses at a CANACINTRA fair.

The consumer perception study was carried out with 19 randomized volunteers who evaluated the three types of cheese in monadic series. The cheeses' identity was unknown to the panelists. The following acceptability characteristics were evaluated: general appearance, aroma, taste, texture, and general acceptance. A nine-point hedonic scale was used $(1=$ dislike extremely, $5=$ neither like nor dislike, and $9=$ like extremely) (Frizzi-Amayo et al., 2019). Saltiness, acidity, and creaminess were evaluated on the ideal point scale (JustAbout-Right, JAR) (Prinyawiwatkul, 2011; Fernandez-Segobia et al., 2018), with three levels of taste perception for each of these attributes: 1, little; 2, adequate; and 3, exceeded. Histograms were developed, drawing a graph of the response percentage of the scale in the three mentioned levels for each cheese. Student t tests with known mean were carried out in order to evaluate if the responses that did not fall into the "adequate" category were significantly different (Lawless and Heymann, 2010). A penalties analysis was also made, based on the proposals of Lawless and Heymann (2010) and Narayanan et al. (2014): the JAR scale is combined with the general acceptance scale to obtain a graph of penalties for the evaluation of the potential impact of being outside the "adequate" level on the product general acceptability. The procedure was as follows (Lawless and Heymann (2010)): (1) the general acceptability $\underline{x}$ of the categories $(1,2,3)$ was obtained; (2) the $\underline{x}$ category 2 - $\underline{x}$ category 3 and $\underline{x}$ category 2- $\underline{x}$ category 1 subtractions were made; (3) A table and scatterplot were 
developed from the scores of differences resulting from the penalty related to the percentage of the total panel of consumers in each category.

For the rank tests, each panelist evaluated 3 cheese samples to qualify their preference: from 1 (most preferred) to 3 (least preferred). The scores were processed to make multiple comparisons between the data of the three types of cheeses, according to the procedures of Christensen et al. (2006).

\section{Statistical analysis}

An ANOVA and Tukey mean difference tests were carried out in the SPSS software ver. 15, to determine the significant differences between the sensory attributes of the cheeses: appearance, taste, aroma, and general acceptability. Excel was used to analyze the JAR data. SPSS ver. 15 was used for the one-way $v s$. known mean t-test. Multiple comparisons were made according to the procedures proposed by Christensen et al. (2006) for the analysis of the range tests.

\section{RESULTS AND DISGUSSIONS}

No differences were found in the aroma, taste, and texture of the cheeses $(p>0.05)$. Montero cheese obtained the highest qualifications for all attributes (Table 2).

The cheeses' characteristics that presented significant differences were appearance and acceptance $(\mathrm{p}>0.05)$ (Table 2). The appearance of CP had a lower rating than Montero $(\mathrm{p}<0.05)$, but did not have differences with respect to Sta. Teresa $(\mathrm{p}>0.05)$. The appearance of CP and Sta. Teresa fell into the category of "I like it moderately", while Montero fell into the category of "I like it a lot". Regarding general acceptance, the CP cheese had a significantly lower acceptance than the Sta. Teresa and Montero cheeses $(\mathrm{p}<0.05)$.

Villegas de Gante et al. (2011) conducted a global consumer acceptability study on 12 samples of double cream cheeses. The acceptability averages ranged from 5.18 to 6.78. In our study the values are higher, possibly because we restricted the study to the 3 most prestigious companies in the region: Sta. Teresa from Huimanguillo, Montero from Malpaso, and Caobanal. The Sta. Teresa brand is so recognized and appreciated that there are several imitations in the market. Although they did not have such a high acceptability, the CP cheeses obtained a 7.0+ score; therefore, they represent an opportunity to offer this product to the market. This value is higher than the average value of Villegas de Gante's study.

Table 2. Degree of liking of Appearance, flavor, taste texture and overall liking of cheeses made either with raw or pasteurized milk.

\begin{tabular}{l|c|c|c|c|c}
\hline Degree of liking & Homogeneity of variances & Significance & GP & STA. TERESA & MONTERO \\
\hline Appearance & 0.20 & 0.03 & $7.1^{\mathrm{a}}$ & $7.2^{\mathrm{ab}}$ & 7.3 \\
\hline Flavour & 0.05 & 0.12 & 7.1 & $7.0^{\mathrm{b}}$ & 7.9 \\
\hline Taste & 0.82 & 0.09 & 7.1 & 7.3 & 7.9 \\
\hline Texture & 0.23 & 0.11 & 6.5 & 7.5 \\
\hline Overall liking & 0.61 & 0.001 & $6.8^{\mathrm{a}}$ & $6^{\mathrm{b}}$ & $8.1^{\mathrm{bc}}$ \\
\hline
\end{tabular}

*Results with different letters are significantly different $(\mathrm{P}<0.05)$. The values represent the mean of the evaluation of 19 consumers using the 9-point hedonic scale. 
An analysis of the saltiness, acidity, and creaminess attributes - measured with the JAR scale - is presented in Figures 1, 2, and 3, respectively. The histograms show that the CP and Sta. Teresa cheeses had certain biases in relation to the "adequate" category,

\section{Salt level:}

How would you rate the salt intensity of this product?

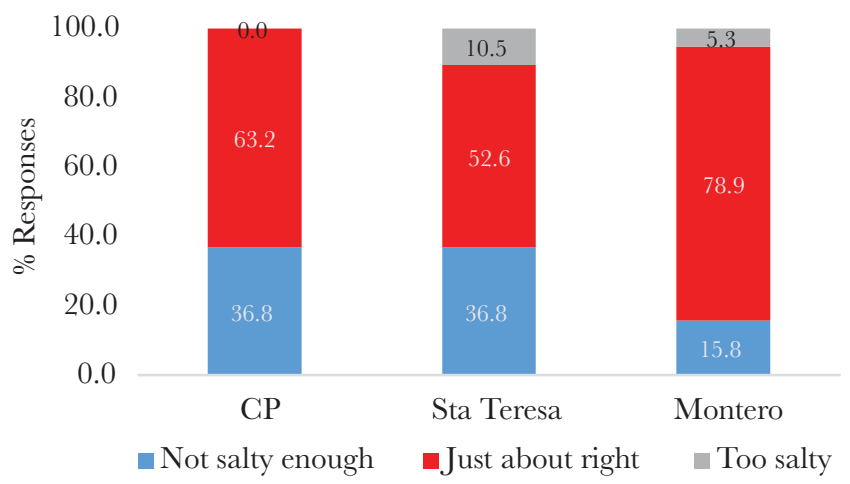

Figure 1. Just-about-right (JAR) scale response percentages for the level of salt in cheese grouped into three levels: not enough, just about right, too much.

\section{Acidity level}

How would you rate the acid intensity (sourness) of this product?

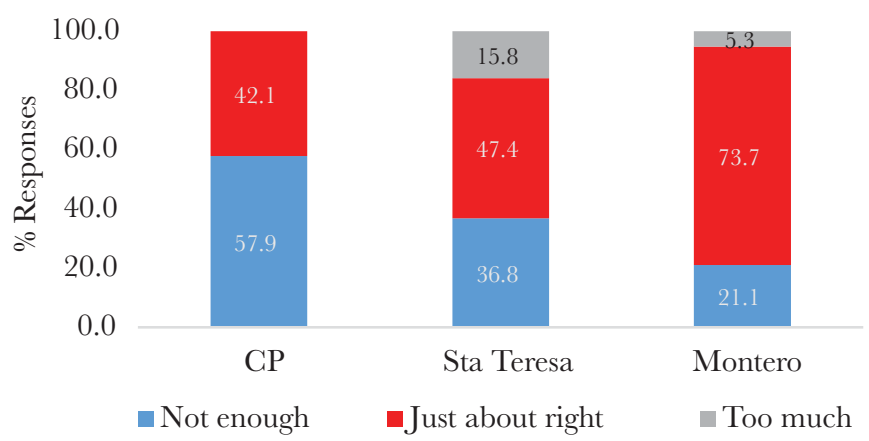

Figure 2. Just-about-right (JAR) scale response percentages for the level of acidity in cheese grouped into three levels: not enough, just about right, too much.

\section{Greaminess}

How would you rate the creaminess of this product?

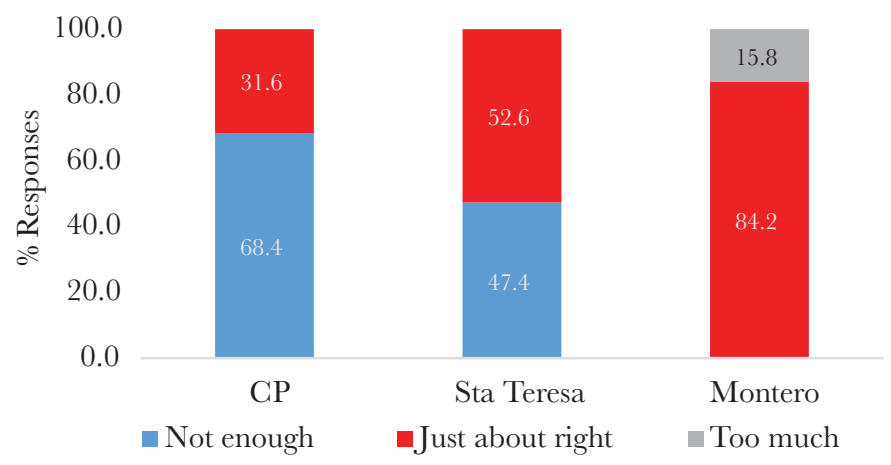

Figure 3. Just-about-right (JAR) scale response percentages for creaminess in cheese grouped into three levels: not enough, just about right, too much. 
oriented towards the "low level of salt", "low level of acidity", and "low level of creaminess" category. The Student $t$ test confirms that the CP cheese was significantly biased from the "adequate" category, as a result of its low salt content $(\underline{x}=1.63 ; p=0.005)$, acidity $(\underline{x}=1.42$; $p=0.00)$, and creaminess $(\underline{x}=1.31 ; p=0.00)$, suggesting that an increase in the saltiness, acidity, and creaminess levels could improve its general acceptability. Sta. Teresa cheese was slightly biased by its low saltiness $(\underline{x}=1.74 ; p=0.1)$ and creaminess $(\underline{x}=1.37 ; p=0.0001)$ levels, but not by its acidity level $(\underline{x}=1.79 ; p=0.21)$. The Montero cheese histograms focused on the "adequate" category and were unbiased with respect to the "adequate" category for any of the three attributes $(\mathrm{p}>0.05)$ : saltiness $(\underline{x}=1.89 ; p=0.33)$, acidity $(\underline{x}=1.84 ; p=0.19)$, and creaminess $(\underline{x}=2.1 ; p=0.16)$. Consequently, we inferred that this cheese does not need changes (Lawless and Heymann, 2010).

A penalty analysis is shown in Figure 4. This is an analysis of the attributes that generated low acceptance ratings (low acidity and creaminess), noted in the upper righthand quadrant.

Therefore, according to these results, in order to increase the acceptance of the CP cheese, we should focus on increasing its acidity and creaminess.

Most people preferred Montero, followed by Sta. Teresa; CP cheese ranked 3rd (Table 3). This result was expected, since both Montero and Sta. Teresa had higher scores in all the attributes of the hedonic scale and were more focused on the "adequate" level in the JAR scale (especially Montero). These results are likely a consequence of the many years that both products have been available on the market. Like many other cheeses, they are the result of a traditional know-how, which is a local heritage, with a reputation linked to the region (Villegas de Gante and Escoto, 2011). This gives them a competitive advantage with a tendency towards acceptance and consumer preference. It is necessary to provide more than just a sentimental and culinary value to the different varieties of artisan cheeses made throughout Mexico. Although consumers appreciate artisan cheeses, they run the risk of disappearing if the intergenerational knowledge transfer is lost.

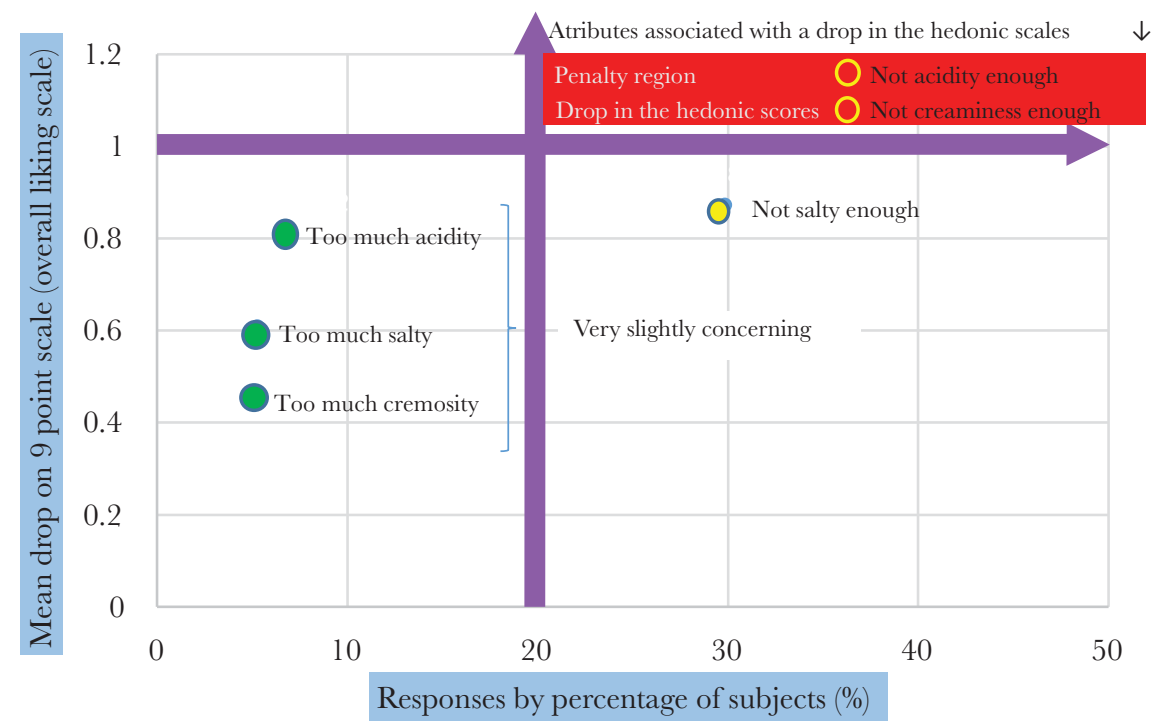

Figure 4. Mean drop analysis as a function of the percentage of subjects 
Table 3. Preference test in the consumption of cheeses.

\begin{tabular}{l|c|c}
\multicolumn{1}{c|}{ Cheese treatments } & Rank sum & Level of preference \\
\hline CP & $47 \mathrm{a}^{*}$ & $3 \mathrm{rd}$ \\
\hline STA. TERESA & $38 \mathrm{ab}$ & $2 \mathrm{nd}$ \\
\hline MONTERO & $29 \mathrm{~b}$ & $1 \mathrm{st}=$ most preferred \\
\hline
\end{tabular}

*Results with different letters are significantly different $(\mathrm{p}<0.05)$.

Pomeón et al. (2011) carried out a strategic analysis about the production and consumption circuit of artisan cream cheese from Chiapas. These are two of the main threats they detected: conflict of interest between cheese makers and the Secretaría de Salud; and the statement that the introduction of pasteurization and other similar processes would cause these cheeses to lose their identity (Pomeón et al., 2011). This study did not intend to compete with raw milk cheeses, but to develop technology to supply markets that are currently not being served; these chesses can be included within the local identity.

A good product requires to build an identity that combines the know-how of microenterprises (better sensory characteristics) with the knowledge of the institutions (better safety). Buchin et al. (1998) compared raw milk and pasteurized milk cheeses; both of them were inoculated with the same amount of starter culture - which is constituted by lactic acid bacteria. Morbier raw milk cheeses from France had a more intense flavor than pasteurized milk cheeses. This difference was the result of the volatile compound profiles. Raw milk cheeses had higher amounts of alcohols, fatty acids, and sulfur compounds than pasteurized milk cheeses — which had higher amounts of ketones.

\section{CONGLUSIONS}

Consumers prefer raw milk cheese over pasteurized milk cheese. Less acidity and less creaminess were associated with a low acceptance rating. Further studies are required to establish if other sensory attributes - in addition to those mentioned in this study - could explain the greater preference and global acceptance of raw milk cheeses.

The results of this work show that using pasteurized milk to prepare double cream cheese is feasible. There were no significant sensory differences in taste, aroma, and texture between raw milk and pasteurized milk cheeses, although the consumers preferred artisan cheeses. Determining if there are other sensory attributes - in addition to those that were the subject of this study - will help to explain the greater preference and global acceptance of raw milk cheeses.

\section{REFERENCES}

Alegbeleye, O., Guimarães, J., Cruz, A., Sant'Ana, A. (2018). Hazards of a 'healthy' trend? An appraisal of the risks of raw milk consumption and the potential of novel treatment technologies to serve as alternatives to pasteurization. Trends in Food Science E Technology, 82, 148-166. Doi:10.1016/j.tifs.2018.10.007.

Atasoy, F., Atilla, Y., Huseyin. T., y Barbaros, O. (2008) Effects of heat treatment and starter culture on the properties of traditional Urfa cheeses (a white-brined Turkish cheese) produced from bovine milk. Food Control, 19 (3).278-285.Doi: 10.1016/j.foodcont.2007.04.004

Bucio, A., Moreno-Tovar, R., Bucio, L., Espinosa-Dávila, J., Anguebes-Franceschi, F. (2021). Characterization of Beeswax, Candelilla Wax and Paraffin Wax for Coating Cheeses. Coatings, 11(3), 261. Doi: 10.3390/ coatings 11030261 
Beuvier, E., Berthaud, K., Cegarra. S., Dasen, A., Pochet, S., Buchin, S., y Duboz, G. (1997). Ripening and quality of swiss type cheese made from raw, pasteurized or microfiltered milk. International Dairy Journal. 7,(5).311-323. Doi:10.1016/S0958-6946(97)00015-0

Buchin, S., Delague, V., Duboz, G., Berdague, J. L., Beuvier, E., Pochet, S., y Grappin, R. (1998). Influence of pasteurization and fat composition of milk on the volatile compounds and flavor characteristics of a semi-hard cheese. Journal of Dairy Science, 81(12), 3097-3108. Doi: 10.3168/jds.S0022-0302(98)75874-6.

Christensen, Z., Ogden, L., Dunn, M., y Eggett, D. L. (2006). Multiple comparison procedures for analysis of ranked data. Journal of Food Science, 71(2), S132-S143. Doi: 10.1111/j.13652621.2006.tb08916.x

Fernández-Segovia, I., García-Martínez, E. M., Fuentes-López, A. (2018). Aplicación de las escalas de punto ideal o Just-About-Right (JAR) en análisis sensorial de alimentos. Departamento de Tecnología de Alimentos. Universitat Politècnica de València.

Frizzi-Amayo, F., Herrera-Corredor, J. A., Alatriste-Pérez, I., y Servín-Juárez, R. (2019). Caracterización fisicoquímica y nivel de agrado de una mermelada artesanal a base de manzana (Malus pumila $\mathrm{cv}$. Golden Delicious) y chayote (Sechium edule). Agroproductividad, 12, 19-25. Doi: 10.32854/agrop. v0i0.1333

Grappin, R., Beuvier, E. (1997). Possible implications of milk pasteurization on the manufacture and sensory quality of ripened cheese. International Dairy Journal, 7(12), 751-761. 10.1016/S0958-6946(98)00006-5

Lawless, H. T., y Heymann, H. (2010). Sensory evaluation of food: principles and practices. Springer Science \& Business Media, New York, Usa.

Montel, M., Buchin, S., Mallet, A., Delbes-Paus, C., Vuitton, D., Desmasures, N., y Berthier, F. (2014). Traditional cheeses: rich and diverse microbiota with associated benefits. International journal of food microbiology, 177, (2).136-154. 10.1016/j.ijfoodmicro.2014.02.019.

Narayanan, P., Chinnasamy, B., Jin, L., Clark, S. (2014). Use of just-about-right scales and penalty analysis to determine appropriate concentrations of stevia sweeteners for vanilla yogurt. Journal of Dairy Science, 97(6), 3262-3272.

Norma Mexicana NMX-F-735-COFOCALEC-2011. Sistema producto leche-alimentos-lácteos-alimento lácteo regional-queso Cotija artesanal madurado-Denominación, Especificaciones y Métodos de prueba. Organismo Nacional de Normalización del Sistema Producto Leche.

Pacheco, F. P., y Bucio, A (2010). Microbial safety of raw milk cheeses traditionally made at a $\mathrm{pH}$ below 4.7 and with other hurdles limiting pathogens growth. Current research, technology and education topics in applied microbiology and microbial biotechnology. Formatex, 789-1620.

Pomeón, T., Boucher, F., y Cervantes Escoto F. (2011). El queso de crema en la Costa de Chiapas: los retos de una construcción colectiva de la calidad. 141-170. En F. Boucher y V. Brun. De la leche al queso: queserías Rurales en América Latina. IICA Q02-08, CIRAD. IICA- Porrúa. México, D.F.

Ramos-Izquierdo, B., Bucio-Galindo, A., Bautista-Muñoz, C., Aranda-lbáñez, E., Izquierdo-Reyes, F. (2009). Aislamiento, identificación y caracterización de bacterias ácido-lácticas para la elaboración de queso crema tropical. Universidad y ciencia, 25(2), 159-171

Romero, P. (2007). Incidencia de salmonella y E. coli en queso crema tropical (estudio de caso en cinco queserías del municipio de Tonalá, Chiapas. Tesis presentada para la obtención del título de maestra en ciencias, en Ciencia y Tecnología Agroalimentaria, UACH, 44 pp.

Tadjine, D., Boudalia, S., Bousbia, A., Khelifa, R., Mebirouk, L., Tadjine, A., Chemmam, M. (2020). Pasteurization effects on yield and physicochemical parameters of cheese in cow and goat milk. Food Science and Technology, 40(3), 580-587. Doi: 10.1590/fst.13119

Villanueva-Valencia, M. (2010). Frecuencia de Brucella spp, Listeria monocytogenes y Escherichia coli O157: H7 en quesos frescos sin pasteurizar colectados en la zona conurbada Veracruz-Boca del Río. Tesis de maestría. Universidad Veracruzana.

Villegas de Gante, A. V., Escoto, F. C. (2011). La genuinidad y tipicidad en la revalorización de los quesos artesanales mexicanos. Estudios Sociales. Revista de Alimentación Contemporánea y Desarrollo Regional, 19(38), 146-164.

Villegas de Gante, A., Santos., A., y Hernández., A. (2011). Caracterización del queso crema de Chiapas. Aspectos socioeconómicos y tipicidad del producto. Universidad Autónoma de Chapingo. lera edición. 128pp.

Yoon, Y., Lee, S., Choi, K.-H. (2016). Microbial benefits and risks of raw milk cheese. Food Control, 63, 201215. Doi: 10.1016/j.foodcont.2015.11.013. 